\title{
ABDUL SAMAD AL-FALIMBANI'S ROLE AND CONTRIBUTION IN THE DISCOURSE OF ISLAMIC KNOWLEDGE IN MALAY WORLD
}

\author{
Mohammed Hussain Ahmad \\ Sultan Sharif Ali Islamic University Brunei Darussalam \\ Email: hussain.ahmad@unissa.edu.bn
}

\begin{abstract}
Shaykh Abdussamad al-Falimbani was an important figure in the intellectual tradition of Islam in the Malay world in the 18th century. This article shows that al-Falimbani played an important role in conveying and developing Islamic sciences, not only in the Malay World even in Arab lands, including in Makkah and in Zabid, Yemen. Al-Falimbani was also one of the superior scholars who not only received recognition from fellow scholars and students from among the Malays, even from his colleagues and students who were Arab. Al-Falimbani's important contribution to the intellectual tradition of Islam in Malay World was: the first, the spread of al-Falimbani's various religious works to various regions of the Islamic world, both in Southeast Asia and the Middle East. Second, the development of intellectual networks of teachers and students in the region of Malay and Middle East in the 18th century. Third, the maintenance of the continuity of Islamic scientific treasures from the classical Islamic scholars to the Muslims in the 18th century even to the modern era today. Fourth, harmonize tasawuf teachings with Islamic law, so that the traditions and rituals of Sufism remain practiced in the corridors of the valid Shari'a.
\end{abstract}

Keywords: Islamic scientific discourse, Malay world, intellectual treasure

\section{Introduction}

The history of the arrival of Islam and the past scholars in the Malay World has attracted the attention of modern scientists and the interests of investigators as material for their writings and studies because it provides a better understanding of the process of Islamization and the intellectual history of the archipelago in a broader context. Ulama from Samudera, Pasai, Aceh, Patani, Ligor, Kedah, Kelantan, Terangganu, Johor, Riau, Batawi, Banten, Singkel, Makassar, Minangkabau, Sumatra, Palembang, Banjar, Pontianak, Sambas, Lingga, Ternate and other countries and regions in the Malay world have been published in sharing the writings of modern scholars. The names of Islamic scholars and scholars in the past such as Hamzah al-Fansuri, Shamsuddin al-Sumatrani, Abdul Rauf al-Sinkili, Nuruddin al-Raniri, Muhammad Yusuf al-Maqassari, Muhammad Arshad al-Banjari, Muhammad Nafis al-Banjari, Abdul Samad al-Falimbani, Daud al-Fatani, Muhammad Nawawi al-Bantani were among the familiar names in Islamic history writing in the Malay World (Azra 2013).

In this context, Palembang and the history of the ulamas are also no exception from attracting the attention of modern scholars. However, slightly different from its predecessor in Aceh, which had been seen giving birth to scholars since the beginning of the sixteenth century, Palembang only emerged with its ulama around the eighteenth century. This undoubtedly shows that from the eighteenth century Palembang began to play an important role in the process of Islamization in the archipelago and eventually replaced Aceh as a new center in learning and spreading Islam. 
One of the eighteenth-century ulamas of Palembang who was prominently prominent was Abdul Samad al-Falimbani himself. Although some information about him has been known by modern scholars, especially through his writings, there is still a lot of space to study his history and his role as an alim and sufi figure, his contribution to the intellectual development of the archipelago and the spread of Islam in the Malay world. There are still works that have not yet been used by modern scholars, including unpublished manuscripts and some of their published works, in addition to new information obtained from classical sources that were never used before that which allows information on Abdul Samad alFalimbani is laid out in detail and is more critical than what has been done so far.

Abdul Samad al-Falimbani was better known as a Sufi figure in the Malay World through his book, his masterpiece (magnum opus) entitled Sayr al-Salikin. Nevertheless, through recitation, teaching and writing, it can be proven that he also has deep knowledge in almost every Islamic religious discipline. This can be understood through his relationship with the famous scholars of his day, the disciplines he learned from them and the evidence that he conveyed these teachings to his students through oral teaching directly or through his work in addition to the testimonies of his peers and his students own. By analyzing scientific relationships with their teachers and students, we can better understand the place and position in the intellectual network of scholars in the eighteenth century and know the role, influence and contribution to the development of Islam in the Malay World.

\section{Al-Falimbani's Brief History}

Al-Falimbani was better known in the historical writing of the Malay World as Sheikh Abdul Samad al-Jawi al-Falimbani. From this ratio shows that he is from Palembang, South Sumatra, which is the second largest island of the Republic of modern Indonesia. Manakala al-Jawi listed in his name shows that he came from the Malay World (Hurgronje 1970, 215).

In summary, the full name of al-Falimbani is Sheikh Abdul Samad bin Abdul Rahman bin Abdul Jalil al-Jawi al-Falimbani (Ahmad 2017, 35-42). And if it is assumed that the name of the descendant of Abdul Jalil is recorded in the Lineage Chronicles (Muhammad 1928, 2067) it is appropriate, we can include salasilah al-Falimbani as Abdul Samad bin Abdul Rahman bin Abdul Jalil bin Abdul Wahhab ibn Ahmad al-Mahdani (perhaps the mistake of the Arabic surname which is supposed to be al-Mahdali or al-Hamdani) comes from Arabic come from Sana'a, Yemen.

When the year of his birth, the author argues that Abdul Samad was born in Palembang around 1132/1719(Ahmad 2017). This is based on research on the age of the scholars who Abdul Samad al-Falimbani studied with them, the death of his teachers, the age of his peers and also the works, which will be explained later.

According to Mal An Abdullah, the information obtained from Abdul Samad's manaqib was called Faydh al-Ihsani wa Midada li al-Rabbani, his birth year was recorded as 1150/1737(M. A. Abdullah 2012, 20-21). However, the results of the author's research, one of Abdul Samad's earliest teachers in Arab Land was [Imaduddin] Yahya b. Umar Maqbul alAhdal (1073-1147 / 1662-1734) who was the Mufti Zabid, Yemen. According to Yasin al-Fadani from Abdul Abdul Samad, he showed that he studied directly al-Bulugh al-Maram by Ibn Hajar al-Asqalani and all his other works from Yahya al-Ahdal by attending his teaching sessions (Fadani (al-) 1980, 17), (Fadani (al-) 1988, 48), (Tarmasi (al-) 1987, 6).

Of all the biographical records of Yahya al-Ahdal (Ahdal (al-) 1979, 22-29); (Zabarah 1956, 880-83), (Zabarah 1956); (Kahhalah 1957, 216); (A. b. U. b. A. b. A. R. al-A. Habshi (al-) 1970, 31-34, 110-11, 217-20, 252-53); (Zirikli (al-) 1998, 161); (Qannuji (al-) 1999, 140-42); 
(Qannuji (al-) 1963, 344-45); (Kattani (al-) 1982, 1135-36); (A. M. al-Y. Habshi (al-) 2004, 37, $72-$ 73, 261, 524-25); (Baghdadi (al-) 1951, 534); (Ahdali (al-) 1940, 123); (Sardar 1996, 27); (Al-Sadiq 2001, 433-34); (Sanusi (al-) 2005, 43); (Brockelmann 1949, 535), clearly shows that he never wandered into the Malay Archipelago as did other Yemeni ulamas and he only went to Makkah to perform the Hajj in 1106/1694 when he met Ahmad al-Nakhli (d. 1130/1717), wrong a muhaddis who was famous in Mecca at that time. So it was impossible for Abdul Samad to meet Yahya al-Ahdal in the Malay world because he had never traveled there, or met in Mecca in 1106/1694 because Abdul Samad himself had not been born at that time. Supposing Yahya died in 1147/1734, then Abdul Samad should have met him most later that year to categorize him as his son's student.

Indeed, the date of birth of 1150/1737 can still be disputed because Abdul Samad has not yet been born if his teacher Yahya died in 1147/1734, while his isnad clearly shows that he belonged to the sons of Yahya al-Ahdal. Further studies need to be carried out to harmonize the arguments of the dates.

As there was a confusion in the date of birth of Abdul Samad, the date he died also was no exception from various different opinions. The results of the research made by the author and the date of haul Abdul Samad were obtained, we can conclude that he died on 17 Zulkaedah 1254 together on February 1, 1839, the year in which the Siamese army attack to Kedah took effect so that they could capture Kedah at that time based on historical records Siam (Ahmad 2017). The latest information obtained says that Abdul Samad's tomb has been found between Sekom Village and Chenok (Amphoe Chana), in the Arrive area, North Patani, Thailand (Al-Husaini 2015).

\section{Al-Falimbani Intellectual Development}

Examining Abdul Samad al-Falimbani's names of teachers and students as well as studying them one by one allows us to cite further information about his intellectual life and scientific activities in Arab Land. However, only a few of Abdul Samad's teachers were known by modern scholars, and the one most often mentioned among them was Muhammad $b$. Abdul Karim al-Samman, Ahmad b. Abdul Mun'im al-Damanhuri, and Muhammad b. Sulaiman al-Kurdi.

When through the research results of Abdul Samad's own writings and the study of isnad that connected them with the previous ulama, the author can impress the names of the teachers and other students, most of which are unknown or mentioned in contemporary studies. Therefore, to examine this aspect adequately, the author has carried out a thorough study of all his known teachers on the Arabian Peninsula and also based on unknown evidence by making a review of his teachers in Egypt and Syria in addition to carrying out critical studies of the His students are known at this time.

By examining Abdul Samad's relationship through extensive scientific networks with his teachers and students, it is not always possible to learn about his relationship with the ulama of his time, but we can also assess his superior position in this network, as well as the important role he plays in delivering Islamic knowledge. In addition, we can also see Abdul Samad's contribution to the development of Islamic science and its learning in the Arab and Malay world. Through research on the relationship between Abdul Samad and his teachers and through his isnad, we can also classify and analyze the various Islamic disciplines that are learned from each teacher such as fiqh, hadith, interpretation, tasawwuf, etc., intellectual thought given to him, and the extent the influence of each teacher individually on it. 
In summary, Abdul Samad has studied with the Zabid scholars in Yemen, Mecca, Taif, Jeddah, Medina, Egypt, Syria, the Maghreb, and the Malay Islands. Teacher Abdul Samad at Zabid including Yahya b. Umar b. Abdul Qadir b. Ahmad al-Ahdal (1073-1147 / 1662-1734), which according to the study the author was his first teacher in the Arab world. Besides Yahya, his teacher at Zabid was [Safiuddin] Ahmad b. Muhammad b. Umar Sharif Maqbul al-Shafi'i al-Ahdal (1109-63 / 1697-1749). Ahmad al-Ahdal was the son of your brother to Yahya al-Ahdal and also his most close student. Amrullah [Khawajah] b. Abdul Khaliq b. al-Zain b. Muhammad Baqi al-Mizjaji al-Hanafi al-Zabidi al-Ash'ari who was the son of a prominent Yemeni Muhaddis, Abdul Khaliq al-Mizjaji (d. 1152/1739). And the last among Abdul Samad's list of teachers identified in Yemen is Ahmad b. Sulaiman [Abu al-Qasim] b. Abu Bakr [Umar Abakr] b. Sulaiman al-Hajjam al-Ahdal al-Husaini al-Ahdali al-Zabidi. Although there is no information about the date of birth and death, from his biography, he was a scholar from Zabid who reportedly lived around 1212/1797.

After studying at Zabid, Abdul Samad continued his journey to Makkah where he had studied with the great scholars. Among the teachers of Abdul Samad in Mecca included [Abu al-Makarim] Salim b. Abdullah al-Basri al-Shafi'i al-Makki (d. 1160/1747), who was the son of the famous muhaddis of Mecca, Abdullah b. Salim b. Muhammad b. Isa al-Basri al-Makki (1049-1134 / 1639-1722), originating from Basrah, Iraq; Sayyid [Abu Hafs] Umar b. Ahmad b. Aqil b. Abu Bakr al-Husaini al-Alawi al-Makki al-Shafi'i, better known as al-Saqqaf (1102-1174 / 1690-1760), was an important cleric in Mecca so he was held as' al-imam al-muhaddith almusnid syeikh al-hadith in the Hijaz, and the star of religion (najm al-din) '; Ata'ullah b. Ahmad b. al-Azhari al-Misri al-Makki al-Shafi'i, an Egyptian cleric who later settled and died in Mecca at the age of ninety (1097-1187 / 1685-1773); [Zainuddin] Abdul Ghani Hilal b. Muhammad Hilal b. Muhammad Sunbul al-Shafi'i (d. 1212/1798), who was a faqih and mufti of Shafi'i in the Holy City of Makkah; [Shihabuddin Abu al-Abbas] Ahmad b. Abdul Munim b. Yusuf b. Siam al-Shafi'i al-Maliki al-Hanafi al-Hanbali al-Damanhuri al-Mazahibi al-Azhari (1101-1192 / 1690-1778), which is better known as Ahmad al-Damanhuri. He was one of the most prominent scholars in the scientific community in the eighteenth century. He is also known as al-Mazahibi because of his authority and knowledge in giving fatwas in all four Sunni schools; [Abu al-Fawz] Ibrahim b. Muhammad b. Abdul Latif b. Abdul Sdunia al-Ra'is al-Zubairi al-Zamzami al-Makki (1110-1195 / 1698-1781); The last ulama in Abdul Samad's list of teachers in Mecca was al-Muhammad Mirdad. The author's investigation in several biographical dictionaries shows him to be Muhammad b. Muhammad Salih b. Muhammad Mirdad al-Hanafi al-Makki (d. 1205/1790).

The teacher Abdul Samad in Taif is [Afifuddin, Abu al-Siadah] Abdullah b. Ibrahim b. Hasan b. Muhammad Amin b. Ali Mirghani al-Husaini al-Nasafi al-Hanafi al-Makki al-Ta'ifi, also known as al-Mahjub (d. 1207/1792), was a famous Sufi Hanafi, born and enlarged in Makkah, and then moved with his family to Taif in 1166/1752. The two sons Abdullah Mirghani, Yasin (w. 1251/1835) were also recognized as al-Mahjub, and Abu Bakr was also a famous Sufi scholar in Makkah.

When one of Abdul Samad's teachers in Jeddah obtained through his sanad is Muhammad Murad b. Yaqub al-Hafiz b. Mahmud al-Ansari al-Khazraji al-Sindi (d. 1201/1786). Muhammad Murad was born to an Indian family in the land of Sindh (now in modern Pakistan), where he grew up and later became Qadi and eventually emigrated to Jeddah.

According to traditional sources, Abdul Samad al-Falimbani is said to have studied for thirty years in Makkah and later five years in Medina. Unfortunately, Abdul Samad himself 
did not provide detailed records of his travel dates and recitations. However, by examining the content of his writing and the date and place where he completed his writing, the author can estimate the five-year date he studied in Medina between 1181/1767 and 1186/1772(Ahmad 2017). Teacher Abdul Samad in Medina including [Abu Abdullah] Muhammad b. Abdul Karim b. Hasan b. Ahmad al-Madani al-Shafi'i, better known as Muhammad al-Samman (1130-89 / 1717-75), was a famous Sufi who was born and died in Medina. Muhammad alSamman was also a highly respected teacher and highly praised by Abdul Samad as he wrote in his writing so that he regarded him as 'spiritual murshid' and 'leader of the guardians of his day' and became his most loyal follower and adored him (Falimbani (al-) n.d., 266).

Abdul Samad received the Tariqat al-Khalwatiyyah al-Sammaniah from Muhammad al-Samman himself and later was appointed as the khalifah of this tariqat. The next teacher Abdul Samad was Abdul Rahman b. Abdul Aziz al-Umari al-Shinqiti al-Maghribi al-Maliki (d. 1181/1767), who was also the son of al-Samman's students; Siddiq b. Umar Khan al-Madani, who was the son of al-Samman's students was also a teacher to Abdul Samad. Although Abdul Samad studied by reading some of us rather than Siddiq Khan on al-Samman's direction, but his relationship with him was more appropriately referred to as a meeting colleague than a teacher to him. This can clearly be seen from the relationship of their meeting, for example, at the request of Abdul Samad, Siddiq Khan wrote for him Qatf Azhar al-Mawahib alRabbaniyyah min Afnan Riyad al-Nafhat al-Qudsiyyah li-Sayyidina al-Shaykh al-Samman, one review of al-Samman's poem is titled al-Nafhat al-Qudsiyyah (Khan 1973, 3). Likewise, according to Abdul Samad, if he himself completed a treatise on speaking wahdat al-wujud based on the teachings he received from al-Samman, Siddiq Khan was the first to read this work and then gave it the title Zad al-Muttaqin fi Tawhid Rabb al-Dunain (Falimbani (al-) n.d.).

Abdul Samad also studied Abdul Ghani b. Abu Bakr b. Abdul Rahman al-Fattani alQasim, which is better known as 'al-Alim al-Sufi al-Hindi al-Madani' who came from India and later settled in Medina studying with al-Samman so he died. Teacher Abdul Samad also included Muhammad b. Solomon al-Kurdi al-Madani al-Shafi'i (1127-94 / 1715-80). He was born in Damascus, Syria and at the age of one year he was brought to Medina where he grew up and was later recognized as a faqih and appointed as Mufti Shafi'i in Medina. His next teacher was Mushayyakh b. Zain Ba-Ubud al-Alawi (d. 1170/1756). He was born in Hadramaut, Yemen and around 1115/1703 emigrated to Medina. The last teacher in the list of teacher Abdul Samad's name in Medina is Aqib b. Hasanuddin b. Jafar b. Muhammad b. Badruddin al-Falimbani al-Sumatrani al-Madani (d. Around 1182/1768), was a Malay scholar who had a large number and wide range of transmission (aktharuhum and wa-awsa'uhum riwayatan) so that he was recognized as a muhaddis, hafiz and faqih (Mamduh 1981, 71).

In general, modern scholars consider that the scientific journey and wandering of Abdul Samad to study is limited to the Arabian Peninsula. However, detailed research on classical sources shows that he also traveled to Egypt and Syria to study with famous clerics from both the Kaherah and Damascus ports. Abdul Samad's teacher list in Egypt includes [Shihabuddin Abu al-Abbas] Ahmad b. Abdul Fattah b. Yusuf b. Umar al-Mujiri al-Shafi'i alAzhari, better known as Ahmad al-Mullawi (1088-1182 / 1677-1767). He studied at Azhar and then became famous for the title of 'master teacher' (shaykh al-shuyukh) and 'expert of the sanad of his day '(musnid al-waqt); [Shihabuddin] Ahmad b. Hasan b. Abdul Karim b. Muhammad b. Yusuf b. Karimuddin al-Karimi al-Khalidi al-Shafi'i al-Qahiri al-Azhari (10961182 / 1684-1768), better known as Ahmad al-Jawhari, because his father was a jeweler (aljawhar); [Shamsuddin Abu Hadi] Muhammad b. Ahmad al-Khalidi al-Shafi'i, was better 
known as Ibn al-Jawhari (1151-1215 / 1738-1800). He was the youngest child to Ahmad alJawhari, so it was held as 'al-Jawhari al-Saghir' (Jawhari Kecil) to distinguish him from his father and also his two brothers, Ahmad b. Ahmad b. Hasan al-Jawhari (1132-87 / 1719-73) and Abdul Fattah b. Ahmad b. Hasan al-Jawhari (1141-1215 / 1728-1800), both of them were also prominent scholars of Egypt; David b. Sulaiman b. Ahmad b. Muhammad b. Umar b. Amir b. Khidr al-Sharnubi al-Burhani al-Kharibtawi al-Misri al-Maliki (1080-1170 / 1669-1757). He was a prominent scholar of hadith so he was given the al-musnid title; [Wajihuddin Abu alMarahim] al-Sayyid Abdul Rahman b. Mustafa b. Shaykh b. Mustafa al-Aydarus al-Husaini al-Tarimi al-Misri al-Shafi'i al-Naqshabandi (1135-93 / 1722-79). Originally from Hadramaut, Yemen and born in Tarim, he then moved to Taif and settled in Egypt; [Abu al-Fayd, Abu alJud, or Abu al-Waqt] al-Sayyid Muhammad Murtada b. Muhammad b. Muhammad b. Abdul Razzaq al-Husaini al-Alawi al-Wasiti al-Biljrami al-Hindi al-Zabidi al-Misri al-Qadiri alNaqshabandi (1145-1205 / 1732-90), was better known as Murtada al-Zabidi. A prominent Hanafi cleric, compiler of dictionaries, linguists, theologians, Sufis, Muhaddis, genealogical experts and biographies (ansab wa rijal). His collection of dictionaries Taj al-Arus may be considered the culmination of classical Arabic dictionaries and strong evidence of his superior scholarship.

The last name in Abdul Samad's list of teachers in Egypt is [Abu al-Hasan, or Abu alNur] Ali b. Abdul Barr b. Abdul Fattah b. Muhammad b. Abu al-Karshi b. Muhammad b. Abdullah al-Halfawi al-Hasani al-Wana'i (or al-Wafa'i) al-Shafi'i al-Ashari al-Khalwati alAzhari al-Misri al-Makki (1170-1211 / 1756-1796). He was born in Kaherah and at the end of his life emigrated to Hijaz and died in Medina.

When the list of Abdul Samad's teachers in Damascus, Syria includes [Shihabuddin Abu al-Abbas] Ahmad b. Ubayd b. Abdullah b. Askar b. Ahmad al-Himsi al-Attar al-Dimashqi (1138-1218 / 1725-1803), was a scholar of the family of al-Attar who was recognized as a muhaddis in Syria in his day; [Shamsuddin Abu Abdullah or Abu al-Awn] Muhammad b. Ahmad b. Salim b. Sulaiman al-Saffarini al-Nabulusi al-Hanbali al-Athari al-Qadiri (1114-1188 / 1702-1774), was born in Saffaran a village near Nablus, Palestine, was a leading scientist and faqih in the Hambali School and a writer who is proficient on various issues; [Sirajuddin Abu Hafs] Umar b. ᄀ Abdul Qadir al-Armanazi al-Halabi al-Shafi'i (1105-48 / 1693-1735); and [Shamsuddin] Muhammad b. Abu al-Fadl Uthman b. Abdul Rahman b. Uthman b. Abdul Razzaq al-Aqili al-Bata'ihi al-Halabi al-Umari al-Shafi'i (1163-1245 / 1749-1829).

The only Maghreb ulama who is known to have a scientific relationship with Abdul Samad is [Abu al-Abbas] Ahmad b. Abdul Aziz b. Rashid b. Muhammad b. Abdul Aziz b. Ali b. Mahmad b. Muhammad b. Baz al-Nawazil Imam Abu Ishaq Ibrahim b. Hilal al-Hilali alSijilmasi al-Maliki, better known as Ahmad al-Hilali (1113-1175 / 1703-1761) and he was born in Sijilmasa, in West Maghribi (Ahmad 2017).

\section{Al-Falimbani's Work}

Abdul Samad's history and educational background shows that he has traveled extensively to various centers of Islamic learning and met with many prominent Islamic scholars of his day and studied in various disciplines from them. He obtained knowledge in each of the major Islamic disciplines, which can be seen from the list of books he read and studied with his teachers through his own notes and also through his sanads encountered.

From this broad principle and worldliness, we naturally expect his own writings and works to reflect learning and world wide knowledge and his meeting with the leading scholars of his time. But if we refer to the available contemporary study of Abdul Samad's life and 
writing, we find that this information is very little specifically related to his work. As of now there has not been one contemporary study that has produced the right information regarding Abdul Samad's writings.

There are eight works that are modernized by modern scholars as a result of Abdul Samad's writing. The results of the research and research of the author himself have subsequently found a number of twelve works attributed to Abdul Samad. This makes the number of all the works of Abdul Samad as many as twenty titles, of which three have been attributed to him.

At least there are two titles that are mistakenly or mistakenly associated with the name Abdul Samad al-Falimbani, namely Anis al-Muttaqin and Tuhfat al-Raghibin. The first title, Anis al-Muttaqin was completed written in 1175/1761 in Arabic and composed by Abdul Samad b. Faqih Husain b. Faqih Muhammad. Shaghir Abdullah was the only scholar who attributed this title to Abdul Samad al-Falimbani, and subsequently assumed that the name Faqih Husain was the name of his father. Shaghir charged that he attributed the title to Abdul Samad based on a manuscript copy of his personal collection (W. M. Abdullah 1996, 131). However, according to research the author, Anis al-Muttaqin was apparently not the result of the writings of Abdul Samad al-Falimbani and Abdul Samad b. Faqih Husain himself is a different author of Abdul Samad al-Falimbani himself (Ahmad 2017).

The second title which is also silap attributed to and considered Abdul Samad's writing is Tuhfat al-Raghibin, a Malay-language work written in 1188/1774 without mentioning the name of the author. Although the work did not mention the name of the author, Voorhoeve was the first person to link this writing with Abdul Samad al-Falimbani, who was later followed by Drewes. He tried to support this charge by presenting five proofs; the strongest of which is Abdul Samad himself usually gives the date he completed his writing between $1178 / 1764$ to $1203 / 1788$. Because Tuhfat al-Raghibin was written in 1188/1774, Voorhoeve concluded that he was the product of Abdul Samad. However, the results of the author's research, Tuhfat al-Raghibin can be proved not by Abdul Samad, but is actually the work of Arshad al-Banjari who has fabricated Tuhfat al-Raghibin fi Bayan Haqiqat Faith al-Mu'minin wa-ma Yufsiduhu min Riddat al-Murtaddin at the request of Sultan Tahmidullah al-Thani b. Sultan Tamjidullah al-Awwal, Sultan of Banjar who ruled around 1778-1808 (Ahmad 2017).

There is another work which is also attributed to Abdul Samad, namely a summary to al-Tuhfah al-Mursalah written by al-Burhanpuri entitled al-Nukhbat al-Mufdah min alRahmat al-Muhdah Alayhi al-Salat wa al-Sdunia min Allah. Through the author's research on the text of al-Nukhbat, he found that he was actually the result of a summary made by Abdullah b. Ibrahim Mirghani and not Abdul Samad (Ahmad 2017).

In summary, the known Abdul Samad writing can be compiled based on the known writing year as follows (Ahmad 2017):

1. Zahrat al-Murid fi Bayan Kalimat al-Tawhid (23 Zulhijjah 1178/12 Jun 1765)

2. Risalah fi Bayan Asbab Muharramat al-Nikah (10 Rabiul Awwal 1179/27 August 1765)

3. Risalah Latifah fi Bayan al-Isra wa al-Mi'raj (11 Rejab 1181/3 Disember 1767)

4. Two letters addressed to two Javanese rulers [19 Safar 1186] / May 22, 1772.

5. Nasihat al-Muslimin wa-Tadhkirat al-Mu'minin fi Fada'il al-Jihad fi Sabilillah waKaramat al-Mujahidin fi Sabilillah (25 Jumadil awwal 1187/14 August 1773)

6. Mulhaq fi Bayan al-Fawa'id al-Nafi'ah fi al-Jihad fi Sabilillah (no date of writing)

7. Doa al-Musabba'at al-Ashar (no date of writing)

8. Al-Urwat al-Wuthqa wa-Silsilat al-Wali al-Atqa (no date of writing)

9. Ratib Syeikh Abdul Samad al-Falimbani (no date of writing) 
10. Kayfiyyat fi Khatm Yawm al-Rabu fi Waqt al-Asr (no date of writing)

11. Al-Risalah fi Kayfiyyat Ratib Laylat al-Jum'ah (no date of writing)

12. Zad al-Muttaqin fi Tawhid Rabb al-Duniain (no date of writing)

13. Hidayat al-Salikin fi Suluk Maslak al-Muttaqin (5 Muharram 1192/3 February 1778)

14. Risalah fi Bayan Hukm al-Shara wa-Bayan man Yukhalifuhu fi al-I'tiqad aw fi al-Hukm aw fi al-Amal (10 Rejab 1201/28 April 1787)

15. Sayr al-Salikin ila Ibadat Rabb al-Duniain (jil. I, 1193-94 / 1779-80; jil. II, 19 Ramadan 1195/8 September 1781; jil. III, 19 Safar 1197/22 January 1783; jil. IV, 20 Ramadan 1203/14 June 1789)

16. Al-Nur al-Ahmad fi Asanid al-Shaykh Abdul Samad (not found)

17. Fada'il al-Ihya li al-Ghazali (not found)18. Puisi Kemenengan Kedah (1246/1831)

In addition, Mal An Abdullah mentioned some of the titles obtained from Faydh alIhsani and the result of Abdul Samad's writing, Sawathi al-Anwar, Irsyad Afdal al-Jihad, and Risalah fi al-Awrad wa al-Adzkar (M. A. Abdullah 2012). Indeed, there is still wide scope for studying and researching the works of Abdul Samad that are available, especially those that are still in the form of unpublished manuscripts and also the newly discovered headlines.

\section{Al-Falimbani's Important Contribution}

Based on the research carried out so far, there has been an important role played by Abdul Samad in the intellectual network of scholars in the eighteenth century. Through his superior position in this intellectual network, Abdul Samad played an important role in conveying and developing Islamic sciences, not only in the Malay World even in Arab lands, including in Makkah and in Zabid, Yemen. He was one of the superior scholars who not only received recognition from peers and students from among the Malays, even from Arab colleagues and students.

One proof of this recognition is the fact that Siddiq al-Madani himself said that alSamman was a famous scholar of his time and had attracted many students and students to study with him, but the most respected students among al-Samman's students and who have benefited a lot from it, and took the greatest light from his teacher, or in his own terms, "wakan min ajalli worldhatihi akhdhan wa a'zamuhum manaran" is Abdul Samad al-Jawi alFalimbani al-Makki (Khan 1973). This fact alone is sufficient to prove clearly that Abdul Samad had gained the highest position among al-Samman's students.

Abdul Rahman al-Ahdal, his student at Zabid, Yemen who was also a Mufti Zabid had included the name and biography of his teacher, Abdul Samad in his thabaqat entitled alNafas al-Yamani wa al-Rawh al-Rayhani. This clearly shows that Abdul Samad was one of the most important teachers for al-Ahdal because he was chosen among hundreds of other scholars who lived at that time to be included in his book. It should be remembered though that there were other Malay scholars who lived contemporaries with Abdul Samad, but none of them found their names and biographies included in the biographies of the Arabic books as happened to Abdul Samad (Ahmad 2017).

In addition, the acknowledgment of Abdul Rahman al-Ahdal's testimony that described him, among others, was the 'great ulama' (al-allamah), 'wali' (al-wali), 'who had deep understanding' (al-fahhamah), 'yang warak' (at-taqi) and 'having a position in the ranks of Islamic scholars' (wajih al-Islam) are enough to give a picture of how great and superior Abdul Samad was in the intellectual network of eighteenth-century scholars, especially in the Arab Land (Ahdal (al-) 1979). 
According to al-Ahdal again, Abdul Samad was one of the scholars who charity with their knowledge (al-ulama al-Amilin) and among those who had the expertise and expertise in almost every Islamic discipline of learning from the ulama of the time from al-Habanyakn scholars al-Sharifain (Makkah and Madinah). He added that Abdul Samad was among productive scholars and masters of knowledge in many fields even though he showed great interest in tasawwuf (Ahdal (al-) 1979).

Among Abdul Samad's biggest contributions was through the work of his Sayr alSalikin. To see clearly the contribution of Abdul Samad to Malay intellectual life, we should refer to the history of the Malay World.

Before the eighteenth century, al-Ghazali and his works were only known and recognized in a limited way in the Malay world through the excerpts of his works which were once published in the writings of earlier scholars from Abdul Samad. However, in the eighteenth century al-Ghazali was widely introduced to the Malay World when Abdul Samad became the first cleric to fully translate his two works, Bidayat al-Hidayah and Lubab or Mukhtasar Ihya Ulum ad-Din. With this translation, Abdul Samad did not place al-Ghazali and his works in the highest place for tasawwuf practicers in the Malay World, but he also indirectly made al-Ghazali's works easily available to be a reference by many people in the Malay World through his translation.

In fact, through Hidayat al-Saikin and Sayr al-Salikin, Abdul Samad has explained to those who are ignorant and those who have been lost, that orthodox al-Ghazali's tasawwuf teachings are harmonious and in accordance with the teachings of Sufi scholars who are often accused of deviating from Shari'a like Ibn al-Arabi, al-Jili, al-Hallaj, al-Jilani, al-Junayd alBaghdadi, and earlier archipelago scholars such as al-Sumatrani and al-Sinkili. In the same period, Abdul Samad also introduced a simple approach of al-Ghazali in which ethics preceded supernatural elements in tasawwuf and emphasized how important it was to obey the Shari'a and its suitability by fulfilling the obligations of religious demands; in this way Abdul Samad sought to draw the crowds back to the mainstream of authentic tasawwuf teaching.

Therefore, it is clear that Abdul Samad's efforts to translate al-Ghazali's works, not to mention his own adaptations and additions, are more than sufficient evidence to highlight Abdul Samad's major and great contribution to the intellectual and spiritual development of the Malays, by shaping social-religious life in the Malay World. In addition, many additions which originated from various books that were extracted and published in their translations indirectly brought the treasures of the works of Islamic scholars to the Malay World, which before this were not easily obtained and were not even known by them. Thus, the work of Abdul Samad, especially Sayr al-Salikin and Hidayat al-Salikin, should be recognized as the causative agent that brought al-Ghazali's influence to the Malay World primarily through Ihya and other works.

\section{Conclusion}

The discovery of new information relating to the history of life, learning, teachers, students, shipping and writing Abdul Samad has opened space for investigators to examine in more depth his role and contribution to the scientific discourse of Islam in the Malay World.

Critical research and in-depth study of new reference sources that have never been used by modern scholars before can provide accurate and valid information about Abdul Samad and his background in life and at the same time help to reconstitute a rather detailed biography of him. 
Through this research and study, it can be seen that Abdul Samad was one of the superior ulama who played an important role in connecting the Arab Land with the Malay World and carrying out the heavy duty of spreading the work and religious sciences of the past scholars to the Archipelago in the eighteenth century. From this study we also know the big and important contributions that have been given by Abdul Samad in helping the intellectual and spiritual development of the Malay World community. Without donations and services like this history and socio-religious life in the Malay World are certainly not what we are currently achieving. 


\section{Bibliography}

Abdullah, Mal An. 2012. “Jejak Sejarah Abdus-Samad Al-Palimbani." Syariah IAIN Raden Fatah Press.

Abdullah, Wan Mohd. 1996. Syeikh Abdus Shamad Palembang: Ulama Shufi Dan Jihad Dunia Melayu. 1st ed. Kuala Lumpur: Khazanah Fathaniyah.

Ahdal (al-), Wajihuddin Abdul Rahman b. Sulaiman b. Yahya al-Yamani. 1979. Al-Nafas AlYamani Wa Al-Rawh Al-Rayhani Fi Ijazat Al-Qudat Bani Al-Shawkani. 1st ed. Sana'a: Markaz ad-Dirasat wa al-Abhath al-Yamaniyah.

Ahdali (al-), Muhammad Adib. 1940. Al-Qawl Al-A'dal Fi Tarajim Bani Al-Ahdal. 1st ed. Homs: Matba'at al-Sharq.

Ahmad, Mohammed Hussain. 2017. "Islam in the Malay World: Al-Falimbani's Scholarship." IIUM Press.

Al-Husaini, Mohd. Abd. Rashid bin Yah al-Kubrawiy. 2015. “Catatan Rehlah Ilmiah Ke Fatani Darussalam (Bagian III)." al-Kubrawiyyah.

Al-Sadiq, Mu'assasat al-Imam. 2001. Mawsu'at Tabaqat Al-Fuqaha. 12th ed. Beirut: Dar al-Adwa.

Azra, Azyumardi. 2013. Jaringan Ulama Timur Tengah-Kepulauan Nusantara Abad XVII Dan XVIII. Jakarta: Kencana Prenda Media Group.

Baghdadi (al-), Ismail Basha. 1951. Hadiyyat Al-Arifin Asma Al-Mu'allifin Wa-Athar AlMusannifin. 2nd ed. Istanbul: Wakalat al-Ma'arif al-Jalilah.

Brockelmann, Carl. 1949. Geschichte Arabischen Litterature. Leiden: E. J. Brill.

Fadani (al-), Abu al-Fayd Muhammad Yasin b. Isa al-Makki. 1980. Al-Iqd Al-Farid Min Jawahir Al-Asanid. 2nd ed. Surabaya: Dar al-Saqaf.

- - . 1988. Al-Wafi Bi-Dhayl Tidhkar Al-Masafi Bi-Ijazat Al-Fakhr Abd Allah b. Abd Al-Karim AlJarafi Wa Al-Safi Ahmad b. Ahmad Al-Jarāfì. 1st ed. Beirut: Dar al-Basha'ir al-Islamiyyah.

Falimbani (al-), Abdul Samad b. Abdul Rahman al-Jawi. Sayr Al-Salikin Ila Ibadat Rabb AlAlamin. 4th ed. Beirut: Dar al-Fikr.

Habshi (al-), Abdullah Muhammad al-Yamani. 2004. Masadir Al-Fikr Al-Islami Fi Al-Yaman. Abu Dhabi: al-Majma' al-Thaqafi.

Habshi (al-), Aydarus b. Umar b. Aydarus b. Abdul Rahman al-Alawi. 1970. Uqud Al-La'al Fi Asanid Al-Rijal. 1st ed. Kaherah: Matba'at Lajnat al-Bayan al-Arabi.

Hurgronje, Christiaan Snouck. 1970. Mekka in Later Part of 19th Century. ed. J. H. Monahan. Leiden: E. J. Brill.

Kahhalah, Umar Rida. 1957. Mu'Jam Al-Mu'Allifin Tarajim Musannifi Al-Kutub Al-Arabiyyah. Beirut: Dar Ihya al-Turath al-Arabi.

Kattani (al-), Abdul Hayy b. Abdul Kabir. 1982. Fahras Al-Faharis Wa Al-Athbat Wa-Mu'jam AlMa'ajim Wa Al-Mashikhat Wa Al-Musalsalat. Beirut: Dar al-Gharb al-Islami.

Khan, Siddiq b. Umar al-Madani. 1973. Qatf Azhar Al-Mawahib Al-Rabbaniyyah Min Afnan Riyad Al-Nafhat Al-Qudsiyyah Li-Sayyidina Al-Shaykh Al-Samman. 1st ed. ed. Ahmad Abd alMajid Haridi. Kaherah: Ahmad al-Badawi al-Sammani al-Tibi.

Mamduh, Abu Sulaiman Mahmud Said b. Muhammad Mamduh al-Qahiri al-Misri al-Shafi'i. 1981. I'lam Al-Qasi Wa Al-Dani Bi-Ba'd Ma Ala Min Asanid Al-Fadani: Wahuwa Thabat AlAllamah Al-Mutafannin Musnid Al-Hijaz Al-Shaykh Alamaddin Muhammad Yasin $b$. Muhammad Isa Al-Fadani Al-Makki Al-Shafi'I. 1st ed. Kaherah: Dar Marjan li al-Tiba'ah.

Muhammad, Muhammad Hassan bin Dato' Kerani. 1928. Tawārīkh Silsilah Negeri Kedah. Pulau Pinang: Jelutong Press. 
Qannuji (al-), Abu al-Tayyib Siddiq b. Hasan b. Ali al-Husayni al-Bukhari. 1963. Taj AlMukallal Min Jawahir Maathir Al-Tiraz Al-Akhir Wa Al-Awwal. 2nd ed. Bombay: al-Matba'at al-Hindiyyah al-Arabiyyah.

- - . 1999. Abjad Al-Ulum. 3rd ed. Beirut: Dar al-Kutub al-Ilmiyyah.

Sanusi (al-), Rida b. Muhammad Safiuddin. 2005. Musnid Al-Hijaz: Al-Thabat, Khatimat AlMuhaddithin Al-Shaykh Abd Allah b. Salim Al-Basri Al-Makki. Jeddah: Markaz al-Nashr alIlmi Jamiat al-Malik Abd al-Aziz.

Sardar, Ahmad b. Muhammad al-Halabi al-Shafi'i. 1996. Bulugh Amani Al-Abrar. Halab: Dar al-Qalam al-Arabi.

Tarmasi (al-), Muhammad Mahfuz b. Abdullah b. Abdul Mannan al-Jawi. Tahqiq Muhammad Yasin b. Muhammad Isa al-Fadani al-Makki. 1987. Kifayat Al-Mustafid Li-Ma Ala Lada AlTarmasi Min Al-Asanid. 5th ed. Beirut: Dar al-Basha'ir al-Islamiyyah.

Zabarah, Muhammad b. Muhammad b. Yahya al-Hasani al-Yamani al-San'ani. 1956. Nubala Al-Yaman Bi Al-Qarn Al-Thani Ashar Li Al-Hijrah Wahuwa Al-Qism Al-Thani Min Aqsam Nashr Al-Urf Li-Nubala Al-Yaman Ba'da Al-Alf Ila 1375 Hijriyyah. 2nd ed. Kaherah: alMatba'at al-Salafiyyah.

Zirikli (al-), Khayruddin. 1998. Al-Alam Qamus Tarajim Li-Ashar Al-Rijal Wa Al-Nisa Min AlArab Wa Al-Muta'arribin Wa Al-Mustashriqin. 8th ed. Beirut: Dar al-Ilm li al-Malayin. 